\title{
REVIEW OF TOTAL KNEE ARTHROPLASTY AND THE BRAZILIAN UNIFIED HEALTH SYSTEM: A NATIONAL PROBLEM
}

\author{
REVISÃO DE ARTROPLASTIA TOTAL DE JOELHO E O SISTEMA \\ ÚNICO DE SAÚDE: UM PROBLEMA NACIONAL
}

\author{
lucas da Ponte Melo ${ }^{1}$, Guilherme augusto losso ${ }^{1}$, Guilherme Henrique Ricardo da Costa ${ }^{1}$, José Ricardo Pécora ${ }^{1}$, \\ marco Kawamura Demange ${ }^{1}$, Camilo Partezani Helito ${ }^{1}$
}

1. Universidade de São Paulo, Faculdade de Medicina, Hospital das Clínicas, Instituto de Ortopedia e Traumatologia, Grupo do Joelho, São Paulo, SP, Brazil.

\section{ABSTRACT}

Objectives: To analyze, through DATASUS data, the historical trend of revision of total knee arthroplasty (TKA) in the period between 2008-2016 and to relate them to demographic, regional and national aspects. Methods: Elaboration of a historical series between the period 2008-2016, using the database of DATASUS, in the area of Health Information (TABNET). In order to calculate the incidence, the total number of TKA revisions and as denominator the total national, regional or state population for the period studied was used as numerator. Results: The national rate of procedures per 100,000 inhabitants varied between 0.41 and 0.48 in the analyzed period (mean of 0.44). The Southeast region, with $69 \%$ of the SBCJ accredited services and $61 \%$ of the SBCJ members, was responsible for $60 \%$ of the absolute number of procedures performed in Brazil. Conclusions: In absolute numbers, the Southeast region has the highest volume of procedures. However, the highest rate is found in the South region. The North, Northeast and Central-West regions presented unsatisfactory results, well below the others. Level of evidence IV, Economic and decision analysis - development of economic model or decision.

Keywords: Reviews. Arthroplasty. Knee. Public Health. Osteoarthritis.

\section{RESUMO}

Objetivos: Analisar, através dos dados do DATASUS, a tendência histórica das revisões de artroplastia total de joelho (ATJ) no período entre 2008-2016 e relacioná-las com aspectos demográficos, regional e nacionalmente. Métodos: Elaboração de uma série histórica entre o período de 2008-2016, utilizando-se do banco de dados do DATASUS, na área de Informações de Saúde (TABNET). Para calcular a incidência, foi usado como numerador o total de revisões de ATJ e como denominador a população total nacional, da região ou do estado pelo período estudado. Resultados: A taxa nacional de procedimentos por 100.000 habitantes apresentou variação entre 0,41 e 0,48 no período analisado (média de 0,44). A região Sudeste, onde estão 69\% dos serviços credenciados à SBCJ e 61\% dos membros titulares da SBCJ, foi responsável por $60 \%$ do número absoluto de procedimentos realizados no Brasil. Conclusões: Em números absolutos, a região Sudeste possui o maior volume de procedimentos. Entretanto, a taxa mais alta é encontrada na região Sul. As regiões Norte, Nordeste e Centro-Oeste apresentaram resultados insatisfatórios, bem abaixo das demais. Nível de evidência IV, Análises econômicas e de decisão-desenvolvimento de modelo econômico ou de decisão.

Citation: Melo LP, Losso GA, Costa GHR, Pécora JR, Demange MK, Helito CP. Wei TH. Review of total knee arthroplasty and the brazilian unified health system: a national problem. Acta Ortop Bras. [online]. 2019;27(5):252-6. Available from URL: http://www.scielo.br/aob.

\section{INTRODUCTION}

The progressive aging of the population is a worldwide phenomenon. As a result, there is an increase in the prevalence of osteoarthritis $(\mathrm{OA})$ and, consequently, in the number of total knee arthroplasties (TKA) performed, a cost-effective procedure with good clinical results. ${ }^{1}$

With the greatest number of TKA, invariably, there is a growing need for review procedures, ${ }^{1}$ which are technically more difficult and more costly, with an estimated cost of $\$ 75,000$ per procedure in the United States. ${ }^{2}$ There are no published current epidemiological studies in Brazil that quantify the number of surgeries performed for TKA revision. The survival rate and clinical outcomes of revision of arthroplasties are lower than the primary TKA, so that their performance should preferably be in specialized centers and with experienced surgeons. ${ }^{3}$ However, it is known that there is no such distinction by specialized centers in our environment, so that any service is authorized to perform these procedures.

According to studies of published TKA indications, the main causes of failure are aseptic loosening, instability and infection. Lombardi $\mathrm{Jr}$ et $\mathrm{al}^{3}{ }^{3}$ in a multicentric analysis of 844 cases of TKA revision, found aseptic loosening (31.2\%) as the predominant mechanism of failure in primary TKA, followed by instability (18.7\%) and infection (16.2\%), with mean time to failure of 5.9 years. These data are in agreement with those published by Khan et $\mathrm{al},{ }^{4}$ with aseptic loosening (29.8\%), infection (14.8\%) and pain (9.5\%) as the main indications for revision.

All authors declare no potential conflict of interest related to this article.

Work conducted at Universidade de São Paulo, Faculdade de Medicina, Instituto de Ortopedia e Traumatologia, São Paulo, SP, Brazil.

Correspondence: Lucas da Ponte Melo. R. Dr. Ovídio Pires de Campos, 333, Cerqueira César, São Paulo, SP, Brazil.05403-010.nlucasmelomed@gmail.com 
Unfortunately, because of the difficulty in dealing with bone loss and the lack of soft tissues present in these cases, the results of the revisions are not as predictable as in cases of primary arthroplasties, ${ }^{5}$ and may lead to catastrophic evolutions, such as arthrodesis and, in the last case, amputations, which greatly impairs patients' quality of life. Unlike trauma-related amputations, the outcome of transfemoral amputations after uncontrolled TKA infection is not satisfactory, with few patients resuming the ability to ambulate. Helito et al, ${ }^{6}$ in a series of cases, showed that only $25 \%$ of the patients undergoing amputation in this context were able to maintain the ability to ambulate.

Thus, trying to establish a national epidemiological profile, in order to understand how we deal with revisions of arthroplasty in our country, the objective of the present study is to evaluate the historical trend of revision of TKA performed by the Public Healthcare Service (Sistema Único de Saúde - SUS), analyzing regional differences and comparing findings with existing data from other countries. In addition, as a secondary objective, to establish a parallel between the number of reviews of TKA performed and the number of services accredited to the Brazilian Society of Knee Surgery (Sociedade Brasileira de Cirurgia do Joelho - SBCJ).

\section{OBJECTIVE}

To analyze, through DATASUS data, the historical trend of revision total knee arthroplasty (TKA) in the period between 2008-2016 and to relate it to demographic aspects, at a regional and national level.

\section{MATERIALS AND METHODS}

A research was performed using the DATASUS database, in the area of Health Information (TABNET). After definition of the period between
2008 and 2016, the procedure "0408050055 ARTROPLASTIA TOTAL DE JOELHO - REVISAO / RECONSTRUCAO" was selected as a filter. ${ }^{7}$ To calculate the incidence, the total of revisions of TKA was used as numerator and the total national, regional or state population for the period studied was used as denominator. Population data were obtained by the National Census of the Brazilian Institute of Geography and Statistics (Instituto Brasileiro de Geografia e Estatística - IBGE) and the projections for the other years. The number of accredited services by region/state is available on the SBCJ website. ${ }^{7}$

The obtained results were allocated in tables, according to the studied questions. The main objective of the study was to describe the incidence of TKA review in Brazil.

For the statistical analysis, the data related to the TKA revisions were presented in absolute and percentage values, with a total for Brazil and stratified according to the Region or Federal Unit, in relation to the year of the procedure. The surgery rate was presented by groups of 100,000 inhabitants. Finally, a statistical analysis was performed to allow a descriptive evaluation of the results obtained.

\section{RESULTS}

Between 2008-2016, the nine-year period used for the study, 7,844 TKA revision surgeries were recorded. We highlight the significant contribution of the Southeast region, with $60 \%$ of the absolute number of procedures performed in Brazil, with the state of São Paulo accounting for 37\% of the total national amount (Tables 1, 2, 3). The national rate of procedures per 100,000 inhabitants presented a variation between 0.41 and 0.48 in the analyzed period (mean of 0.44) (Figure 1).

Although the absolute number is much higher in the Southeast region, we highlight that the highest rate of TKA revision is found

Table 1. Hospital procedures of the Brazilian Unified Health System (SUS) - by admission facility location - Brazil.

\begin{tabular}{|c|c|c|c|c|c|c|c|c|c|c|c|c|c|c|c|}
\hline \multicolumn{16}{|c|}{$\begin{array}{l}\text { Hospital admissions by Region/State and Year of processing } \\
\text { Procedure:0408050055 total knee arthroplasty - revision/reconstruction - Period:2008-2016 }\end{array}$} \\
\hline \multirow{2}{*}{ Region/State } & \multicolumn{3}{|c|}{2008} & \multicolumn{3}{|c|}{2009} & \multicolumn{3}{|c|}{2010} & \multicolumn{3}{|c|}{2011} & \multicolumn{3}{|c|}{2012} \\
\hline & Surgeries & Population & Rate & Surgeries & Population & Rate & Surgeries & Population & Rate & Surgeries & Population & Rate & Surgeries & Population & Rate \\
\hline Acre & 19 & 705.635 & 2.69 & 13 & 720.132 & \begin{tabular}{|l|}
1.81 \\
\end{tabular} & 1 & 733.559 & 0.14 & 1 & 746.375 & 0.13 & 3 & 758.786 & 0.40 \\
\hline Amapá & 0 & 651.977 & 0.00 & 0 & 669.360 & 0.00 & 0 & 669.526 & 0.00 & 0 & 684.301 & 0.00 & 0 & 698.602 & 0.00 \\
\hline Amazonas & 10 & 3.463 .562 & 0.29 & 10 & 3.534 .456 & \begin{tabular}{|l|}
0.28 \\
\end{tabular} & 6 & 3.483 .985 & 0.17 & 2 & 3.538 .359 & 0.06 & 1 & 3.590 .985 & 0.03 \\
\hline Pará & 36 & 7.402 .515 & 0.49 & 15 & \begin{tabular}{|l|}
7.521 .656 \\
\end{tabular} & \begin{tabular}{|l|}
0.20 \\
\end{tabular} & 46 & 7.581 .051 & 0.61 & 9 & 7.688 .531 & 0.12 & 8 & $\begin{array}{l}7.792 .561 \\
\end{array}$ & 0.10 \\
\hline Rondônia & 0 & 1.616 .992 & 0.00 & 0 & 1.640 .607 & 0.00 & 0 & 1.562 .409 & 0.00 & 1 & 1.576 .423 & 0.06 & 1 & 1.590 .011 & 0.06 \\
\hline Roraima & 0 & 440.533 & 0.00 & 0 & 450.969 & \begin{tabular}{|l|}
0.00 \\
\end{tabular} & 0 & 450.479 & 0.00 & 0 & 460.157 & 0.00 & 0 & 469.524 & 0.00 \\
\hline Tocantins & 8 & 1.376 .898 & 0.58 & 1 & 1.398.334 & $\mid 0.07$ & 6 & 1.383 .445 & 0.43 & 1 & 1.400 .813 & 0.07 & 3 & 1.417 .694 & 0.21 \\
\hline Alagoas & 4 & 3.177 .975 & 0.13 & 1 & 3.205 .791 & \begin{tabular}{|l|}
0.03 \\
\end{tabular} & 5 & 3.120 .494 & 0.16 & 3 & 3.143 .338 & 0.10 & 3 & 3.165 .472 & 0.09 \\
\hline Bahia & 10 & 14.558 .148 & 0.07 & 17 & 14.665 .810 & \begin{tabular}{|l|}
0.12 \\
\end{tabular} & 12 & 14.016 .906 & 0.09 & 15 & 14.097 .333 & 0.11 & 16 & 14.175.341 & 0.11 \\
\hline Ceará & 77 & 8.412 .055 & 0.92 & 59 & 8.493 .155 & 0.69 & 13 & 8.452 .381 & 0.15 & 6 & 8.530 .058 & 0.07 & 3 & 8.606 .005 & 0.03 \\
\hline Maranhão & 11 & 6.458 .789 & 0.17 & 4 & 6.533 .027 & \begin{tabular}{|l|}
0.06 \\
\end{tabular} & 3 & 6.574 .789 & 0.05 & 0 & 6.645 .665 & 0.00 & 3 & 6.714 .314 & 0.04 \\
\hline Paraíba & 0 & 3.751 .507 & 0.00 & 2 & 3.785 .598 & 0.05 & 3 & 3.766 .528 & 0.08 & 3 & 3.791 .200 & 0.08 & 4 & 3.815 .171 & 0.10 \\
\hline Pernambuco & 16 & 8.825 .549 & 0.18 & 19 & 8.906 .488 & 0.21 & 7 & 8.796 .448 & 0.08 & 12 & 8.864 .803 & 0.14 & 16 & 8.931 .028 & 0.18 \\
\hline Piauí & 0 & 3.106 .597 & 0.00 & 1 & 3.125 .918 & 0.03 & 4 & 3.118 .360 & 0.13 & 5 & 3.140 .213 & 0.16 & 1 & 3.160 .748 & 0.03 \\
\hline Rio Grande do Norte & 6 & 3.186 .891 & 0.19 & 3 & 3.226 .259 & 0.09 & 7 & 3.168 .027 & 0.22 & 7 & 3.198 .572 & 0.22 & 9 & 3.228 .198 & 0.28 \\
\hline Sergipe & 0 & 2.066 .358 & 0.00 & 0 & 2.093 .507 & 0.00 & 0 & 2.068 .017 & 0.00 & 4 & 2.089 .783 & 0.19 & 1 & 2.110 .867 & 0.05 \\
\hline Espírito Santo & 7 & 3.598 .524 & 0.19 & 13 & 3.648 .075 & \begin{tabular}{|l|}
0.36 \\
\end{tabular} & 20 & 3.514 .952 & 0.57 & 11 & 3.547 .013 & 0.31 & 25 & 3.578 .067 & 0.70 \\
\hline Minas Gerais & 62 & 19.794 .278 & 0.31 & 65 & 19.967 .560 & 0.33 & 68 & 19.597 .330 & 0.35 & 47 & 19.728 .252 & 0.24 & 74 & 19.855 .332 & 0.37 \\
\hline Rio de Janeiro & 40 & 15.859 .866 & 0.25 & 67 & 15.969 .092 & \begin{tabular}{|l|}
0.42 \\
\end{tabular} & 69 & 15.989 .929 & 0.43 & 63 & 16.112 .637 & 0.39 & 74 & 16.231 .365 & 0.46 \\
\hline São Paulo & 334 & 41.651 .651 & 0.80 & 325 & 42.075 .716 & 0.77 & 456 & 41.262 .199 & 1.11 & 385 & 41.586 .892 & 0.93 & 74 & 41.901 .219 & 0.18 \\
\hline Paraná & 33 & 10.540 .407 & 0.31 & 67 & 10.636 .065 & \begin{tabular}{|l|}
0.63 \\
\end{tabular} & 68 & 10.444 .526 & 0.65 & 80 & 10.512 .151 & 0.76 & 74 & 10.577 .755 & 0.70 \\
\hline Rio Grande do Sul & 90 & 10.906 .958 & 0.83 & 88 & 10.965 .071 & \begin{tabular}{|l|}
0.80 \\
\end{tabular} & 88 & 10.693 .929 & \begin{tabular}{|l|}
0.82 \\
\end{tabular} & 111 & 10.732 .770 & 1.03 & 74 & 10.770 .603 & 0.69 \\
\hline Santa Catarina & 29 & 6.164 .049 & 0.47 & 33 & 6.257 .173 & 0.53 & 36 & 6.248 .436 & 0.58 & 35 & 6.316 .906 & 0.55 & 74 & 6.383.286 & 1.16 \\
\hline Distrito Federal & 8 & 2.483 .669 & 0.32 & 6 & 2.541 .434 & \begin{tabular}{|l|}
0.24 \\
\end{tabular} & 4 & 2.570 .160 & 0.16 & 4 & 2.609 .997 & 0.15 & 74 & 2.648 .532 & 2.79 \\
\hline Goiás & 1 & 5.957 .260 & 0.02 & 4 & 6.057.367 & 0.07 & 3 & 6.003 .788 & 0.05 & 3 & 6.080 .588 & 0.05 & 74 & 6.154 .996 & 1.20 \\
\hline Mato Grosso & 1 & 2.956 .496 & 0.03 & 1 & 3.003 .310 & \begin{tabular}{|l|}
0.03 \\
\end{tabular} & 3 & 3.035 .122 & 0.10 & 1 & 3.075 .862 & 0.03 & 74 & 3.115 .336 & 2.38 \\
\hline Mato Grosso do Sul & 0 & 2.417 .300 & 0.00 & 4 & 2.452 .039 & 0.16 & 2 & 2.449 .024 & 0.08 & 2 & 2.477 .504 & 0.08 & 74 & 2.505 .088 & 2.95 \\
\hline
\end{tabular}


Table 2. Hospital procedures of the Brazilian Unified Health System (SUS) - by admission facility location - Brazil.

Hospital admissions by Region/State and year of processing

Procedure:0408050055 total knee arthroplasty - revision / reconstruction -Period:2008-2016

\begin{tabular}{|c|c|c|c|c|c|c|c|c|c|c|c|c|}
\hline Region/State & \multicolumn{3}{|c|}{2013} & \multicolumn{3}{|c|}{2014} & \multicolumn{3}{|c|}{2015} & \multicolumn{3}{|c|}{2016} \\
\hline Amapá & 0 & 734.996 & 0.00 & 0 & 750.912 & 0.00 & 0 & 766.679 & 0.00 & 0 & 782.295 & 0.00 \\
\hline Pará & 5 & 7.969 .654 & 0.06 & 10 & 8.073 .924 & 0.12 & 13 & 8.175 .113 & 0.16 & 14 & 8.272 .724 & 0.17 \\
\hline Rondônia & 1 & 1.728 .214 & 0.06 & 0 & 1.748 .531 & 0.00 & 0 & 1.768 .204 & 0.00 & 3 & 1.787 .279 & 0.17 \\
\hline Roraima & 0 & 488.072 & 0.00 & 0 & 496.936 & 0.00 & 0 & 505.665 & 0.00 & 0 & 514.229 & 0.00 \\
\hline Tocantins & 3 & 1.478 .164 & 0.20 & 0 & 1.496 .880 & 0.00 & 1 & 1.515 .126 & 0.07 & 0 & 1.532 .902 & 0.00 \\
\hline Ceará & 6 & 8.778 .576 & 0.07 & 21 & 8.842 .791 & 0.24 & 15 & 8.904 .459 & 0.17 & 10 & 8.963 .663 & 0.11 \\
\hline Maranhão & 3 & 6.794 .301 & 0.04 & 4 & 6.850 .884 & 0.06 & 0 & 6.904 .241 & 0.00 & 3 & 6.954 .036 & 0.04 \\
\hline Paraíba & 11 & 3.914 .421 & 0.28 & 9 & 3.943 .885 & 0.23 & 3 & 3.972 .202 & 0.08 & 2 & 3.999 .415 & 0.05 \\
\hline Pernambuco & 18 & 9.208 .550 & 0.20 & 9 & 9.277 .727 & 0.10 & 14 & 9.345 .173 & 0.15 & 6 & 9.410 .336 & 0.06 \\
\hline Piauí & 2 & 3.184 .166 & 0.06 & 3 & 3.194 .718 & 0.09 & 15 & 3.204 .028 & 0.47 & 9 & 3.212 .180 & 0.28 \\
\hline Rio Grande do Norte & 5 & 3.373 .959 & 0.15 & 7 & 3.408 .510 & 0.21 & 7 & 3.442 .175 & 0.20 & 2 & 3.474 .998 & 0.06 \\
\hline São Paulo & 281 & 43.663 .669 & 0.64 & 330 & 44.035 .304 & 0.75 & 261 & 44.396 .484 & 0.59 & 225 & 44.749 .699 & 0.50 \\
\hline Paraná & 82 & 10.997 .465 & 0.75 & 91 & 11.081 .692 & 0.82 & 111 & 11.163 .018 & 0.99 & 102 & 11.242 .720 & 0.91 \\
\hline Rio Grande do Sul & 133 & 11.164 .043 & 1.19 & 95 & 11.207 .274 & 0.85 & 89 & 11.247 .972 & 0.79 & 88 & 11.286 .500 & 0.78 \\
\hline Santa Catarina & 60 & 6.634 .254 & 0.90 & 86 & 6.727 .148 & 1.28 & 84 & 6.819 .190 & 1.23 & 71 & 6.910 .553 & 1.03 \\
\hline Distrito Federal & 10 & 2.789 .761 & 0.36 & 8 & 2.852 .372 & 0.28 & 6 & 2.914 .830 & 0.21 & 4 & 2.977 .216 & 0.13 \\
\hline Goiás & 6 & 6.434 .048 & 0.09 & 2 & 6.523 .222 & 0.03 & 5 & 6.610 .681 & 0.08 & 2 & 6.695 .855 & 0.03 \\
\hline Mato Grosso & 2 & 3.182 .113 & 0.06 & 3 & 3.224 .357 & 0.09 & 9 & 3.265 .486 & 0.28 & 3 & 3.305 .531 & 0.09 \\
\hline Mato Grosso do Sul & 2 & 2.587 .269 & 0.08 & 1 & 2.619 .657 & 0.04 & 3 & 2.651 .235 & 0.11 & 4 & 2.682 .386 & 0.15 \\
\hline
\end{tabular}

Table 3. Hospital procedures of the Brazilian Unified Health System (SUS) - by admission facility location - Brazil.

Hospital admissions by Region/State and Year of processing

Procedure:0408050055 total knee arthroplasty - revision/reconstruction - Period:2008-2016

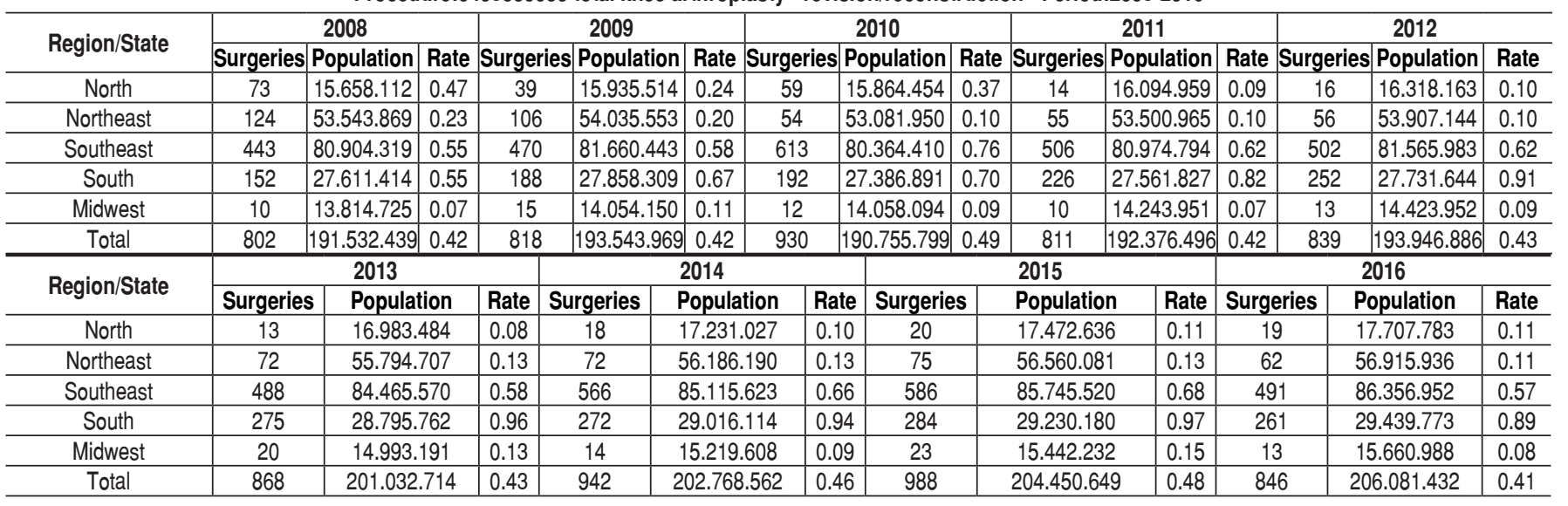

in the South region, with a mean in the studied period of 0.82 per 100,000 inhabitants (Figure 2). Rio Grande do Sul (0.90) and São Paulo $(0.75)$ are the states of the federation with the highest average revision rate of TKA.

On the other hand, the performance of the North (0.19), Northeast $(0.14)$ and Midwest $(0.10)$ regions, evaluated by the average rate in the studied period, is well below the South and Southeast regions, showing a worrying scenario at national level.

After a trend of growth between 2011-2015, the year 2016 presented a national fall in the revision rate of TKA $(15 \%)$, with the Center-West region showing the most intense fall (44\%).

The rate of accredited services and associate members in the SBCJ in 2017 per 10,000,000 population group is shown in table 4.

\section{DISCUSSION}

The analysis of the official data provided by the SUS presents a worrisome national scenario regarding the revision of TKA. The national average rate of $0.44 / 100,000$ inhabitants is well below international indicators. In the state of New York, Bansal et al ${ }^{8}$ showed a growth of $246 \%$ between 1993 and 2010, with the rate increasing from 4.9 to 16.8 / 100,000 inhabitants. Bozic et $\mathrm{al}^{9}$ using the NIS (Nationwide Inpatients Sample) between 2005 and 2010 demonstrated a $39 \%$ increase in the number of TKA revisions in the American population.

This trend of growth, also observed in several other series in Europe, Australia and Canada, ${ }^{10-13}$ contrasts with the decrease in the number 


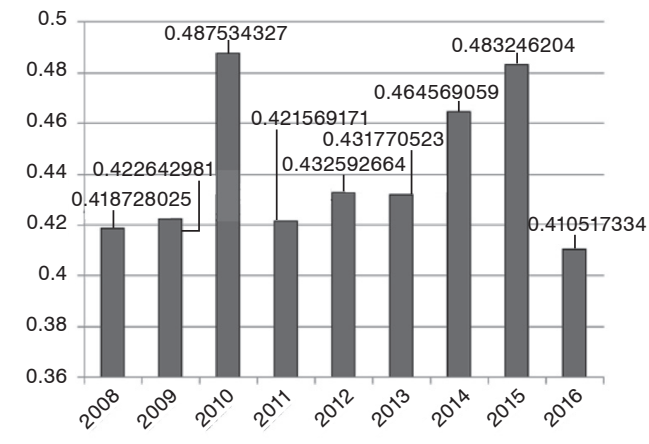

Figure 1. Rate of revision of total knee arthroplasty performed by the Brazilian Unified Health System from 2008 to 2019 (per 100,000 inhabitants)

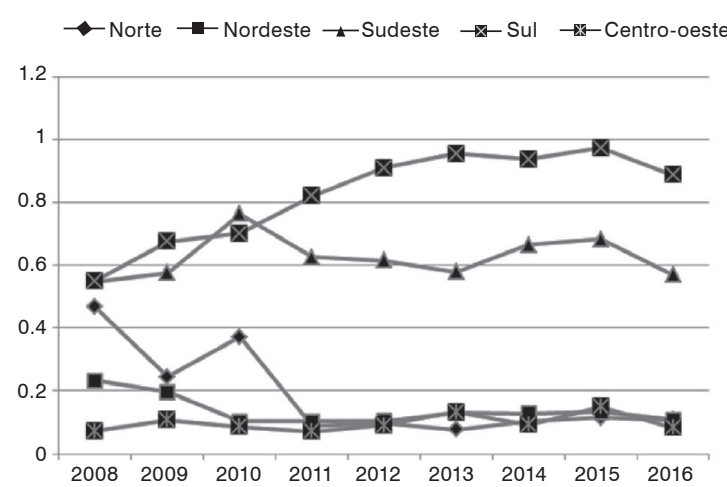

Figure 2. Rate of revision of total knee arthroplasty performed by the Brazilian Unified Health System from 2008 to 2019 (per 100,000 inhabitants)

Table 4. Rate of accredited services and associated members of the Brazilian Knee Surgery Society (SBCJ), by regions of Brazil, in 2017 (per 10,000,000).

\begin{tabular}{c|c|c}
\hline Region & Accredited services & Associated members \\
\hline North & 2 & 36 \\
\hline Northeast & 7 & 194 \\
\hline Southeast & 58 & 867 \\
\hline South & 14 & 222 \\
\hline Midwest & 3 & 96 \\
\hline
\end{tabular}

of TKA revisions made in Brazil in 2016, when there was a reduction of $15 \%$ compared to 2015 , which may eventually be related to a worsening of the country's economic indicators in this period, with a direct impact on the public health system.

In England and Wales, it is estimated that 332\% increase in the number of revisions of TKA between 2012 and 2030.14 In the United States, a $601 \%$ increase in TKA revision demand is estimated in 2030 when compared to $2005 .^{2}$ Although there are no national estimates of the number of TKA revisions in 2030, the chronological evolution shown in figure 1 shows that public health policies are needed for an attempt to reverse this situation.

A recent national publication brought a picture of the primary TKA in the SUS. Between 2008 and 2015, there was an average annual increase of $8.7 \%$ in the number of primary TKA.${ }^{15}$ Comparing with our study, after compiling the data in a linear regression curve, we found a growth of only 12.78 procedures per year. Although we use different parameters in this comparison, there appears to be a lag in the number of revisions, which can not grow analogously to the primary procedures.

The delay in performing the TKA review procedure, after its indication, is associated with an increase in complications and technical difficulties. Unresolved loosening tend to provoke a positive feedback in the process of osteolysis and bone loss. The need for endoprosthetic reconstruction, as an alternative to rescue the limb, has worse results, with higher infection rates and a greater need for further revisions. ${ }^{16}$ In cases of prolonged use of the cement spacer, late follow-up showed mechanical failure in $87 \%$, with supracondylar fractures and spacer dislocation being the most common complications. ${ }^{17}$

As shown in table 4, there is a large regional disparity in the rate of accredited services and members associated with SBCJ, with more than $50 \%$ of services and members of society being in the Southeast region. This reflects a national lack of reference centers for conducting a revision of TKA. Jeschke et al, ${ }^{18}$ showed a clear association between the need for revision after a primary TKA and the surgical volume of the hospital where the procedure was performed. These data allow extrapolations for cases of TKA revisions. Because it is a high-cost, large-scale procedure with many complications, it is important to create regional centers of excellence, with professionals trained to perform this procedure, seeking better results and optimizing public health policy.

We know that underreporting makes it difficult to interpret the Brazilian TKA revisions more reliably. With use in the United States and the United Kingdom, the American Joint Replacement Registry ${ }^{19}$ and the National Joint Registry ${ }^{20}$ are important tools for the prospective monitoring of performed arthroplasties and implant surveillance, generating a broader national perspective, rather than a purely institutional view. This reinforces the need to create a brazilian registry of implants, facilitating control and helping to guide decisions about investments and improvements to be made in the SUS network care.

The fact that we use data only from the SUS generates a limitation to our study, since we can not size the impact of the revision of TKA in the supplementary health system, which is responsible for an important portion in the total amount of cases. In addition, a statistical analysis based on numbers alone may not reflect the presence of good services, which certainly exist in all regions of the country, with a qualified team that, although perform a low number of procedures.

\section{CONCLUSIONS}

In Brazil, an average rate of TKA revisions was 0.44 per 100,000 inhabitants between 2008 and 2016. In absolute numbers, the Southeast region has the highest volume of procedures. However, the highest rate found is in the South region. $69 \%$ of the services accredited to the SBCJ and $61 \%$ of the SBCJ members are in the Southeast region.

AUTHORS' CONTRIBUTIONS: Cada autor contribuiu individualmente e significativamente para o desenvolvimento do artigo intitulado "Panorama das revisões de artroplastia total de joelho no contexto do Sistema Único de Saúde: um problema nacional": LPM (0000-0002-1965-2100)*: pesquisa, levantamento de dados, análise estatística; GAL (0000-0002-9484-7717)*: pesquisa, levantamento de dados, análise estatística, redação do texto, revisão bibliográfica; GHRC (0000-0002-1409-3178)*: pesquisa, análise estatística, redação do texto, revisão bibliográfica; JRP (0000-0003-0287-4548)*: idealização, orientação da pesquisa; MKD (0000-0003-1999-9478)*: idealização, orientação da pesquisa, orientação da escrita do texto; CHP (0000-0003-1139-2524)*: idealização, orientação da pesquisa, orientação da escrita do texto. *ORCID (Open Researcher and Contributor ID). 


\section{REFERENCES}

1. Kurtz S, Ong K, Lau E, Mowat F, Halpern M. Projections of primary and revision hip and knee arthroplasty in the United States from 2005 to 2030. J Bone Joint Surg Am. 2007;89(4):780-5.

2. Delanois RE, Mistry JB, Gwam CU, Mohamed NS, Choksi US, Mont MA. Current Epidemiology of Revision Total Knee Arthroplasty in the United States. J Arthroplasty. 2017;32(9):2663-8.

3. Lombardi Jr AV, Berend KR, Adams JB. Why knee replacements fail in 2013. Bone Joint J. 2014;96-B(11 Suppl A):101-4.

4. Khan M, Osman K, Green G, Haddad FS. The epidemiology of failure in total knee arthroplasty. Bone Joint J. 2016;98-B(1 Suppl A):105-12.

5. Lee DH, Lee SH, Song EK, Seon JK, Lim HA, Yang HY. Causes and Clinical Outcomes of Revision Total Knee Arthroplasty. Knee Surg Relat Res. 2017;29(2):104-9.

6. Helito CP, Brito ATS, Gobbi RG, Demange MK, Tirico LEP, Pécora JR, et al. Evaluation of quality of life and walking ability among amputated patients and those refused to undergo amputation following infection of total knee arthroplasty: small case series. Prosthet Orthot Int. 2015;39(6):463-9.

7. Brasil. Ministério da Saúde. Datasus. Informações de Saúde. [Acessado em 16/05/2017] Disponível em: http://www2.datasus.gov.br/DATASUS/index. php?area $=0202 \& \mathrm{id}=11633 \mathrm{e}$ http://tabnet. datasus.gov.br/cgi/deftohtm.exe?sih/ cnv/qruf.def e http://www.ibge.gov.br/apps/populacao/projecao/index.html. e http://www.sbcj.org.br/?credenciados-estados.

8. Bansal A, Khatib ON, Zuckerman JD. Revision total joint arthroplasty: the epidemiology of 63.140 cases in New York State. J Arthroplasty. 2014;29(1):23-7.

9. Bozic KJ, Kamath AF, Ong K, Lau E, Kurtz S, Chan V, et al. Comparative Epidemiology of Revision Arthroplasty: Failed THA Poses Greater Clinical and Economic Burdens Than Failed TKA. Clin Orthop Relat Res. 2015;473(6):2131-8.

10. Sheng PY, Konttinen L, Lehto M, Ogino D, Jamsen E, Nevalainen J, et al.
Revision total knee arthroplasty: 1990 through 2002. A review of the Finnish arthroplasty registry. J Bone Joint Surg Am. 2006;88(7):1425-30.

11. Havelin LI. The Norwegian Joint Registry. Bull Hosp Jt Dis. 1999;58(3):139-47.

12. Australian Orthopaedic Association. National Joint Replacement Registry annual report 2003. [Accessed August, 2012.] www.dmac.adelaide.edu.au/aoanjrr/ documents/aoanjrrreport_2003. pdf; 2003.

13. Canadian Institute for Health Information, Canadian Joint Replacement Registry (CJRR). 2004 report: total hip and total knee replacements in Canada 2004.

14. Patel A, Pavlou G, Mújica-Mota RE, Toms AD. The epidemiology of revision total knee and hip arthroplasty in England and Wales. Bone Joint J. 2015;97-B(8):1076-81.

15. Ferreira MC, Oliveira JCP, Zidan FF, Franciozi CES, Luzo MVM, Abdalla RJ. Artroplastia total de joelho e quadril: a preocupante realidade assistencial do Sistema Único de Saúde brasileiro. Rev Bras Ortop. 2017;53(4):432-40.

16. Barry JJ, Thielen Z, Sing DC, Yi PH, Hansen EN, Ries M. Length of Endoprosthetic Reconstruction in Revision Knee Arthroplasty Is Associated With Complications and Reoperations. Clin Orthop Relat Res. 2017;475(1):72-9.

17. Petis SM, Perry KI, Pagnano MW, Berry DJ, Hanssen AD, Abdel MP. Retained Antibiotic Spacers After Total Hip and Knee Arthroplasty Resections: High Complication Rates. J Arthroplasty. 2017;32(11):3510-8.

18. Jeschke E, Citak M, Gunster C, Matthias AH, Heller KD, Malzahn J, et al. Are TKAs Performed in High-volume Hospitals Less Likely to Undergo Revision Than TKAs Performed in Low-volume Hospitals? Clin Orthop Relat Res. 2017;475(11):2669-74

19. Etkin CD, Springer BD. The American Joint Replacement Registry - the first 5 years. Arthroplast Today. 2017;3(2):67-9.

20. Prime MS, Palmer J, Khan WS. The National Joint Registry of England and Wales. Orthopedics. 2011;34(2):107-10. 